УДК 378.124 .92

(C) Боярська-Хоменко А. В., Золотухіна С. Т., Штефан Л. А., 2021

https://orcid.org/0000-0002-3535-5974

https://orcid.org/0000-0002-1818-3074

https:// orcid.org/0000-0002-6281-980X

DOI 10.34142/23128046.2021.51.04

А. В. Боярська-Хоменко,

С. Т. Золотухіна,

Л. А. Штефан

\title{
ВИХОВНИЙ ПОТЕНЦАЛ КАФЕДРИ ОСВІТОЛОГІЇ ТА ІННОВАЦІЙНОЇ ПЕДАГОГІКИ
}

У статті на основі аналізу діяльності кафедри освітології та інноваиійної педагогіки розкрито ї̈ виховний потенціал. Підкреслено, щзо саме кафедра має створювати умови для розкриття здатності ї̈ членів чітко організовувати процес якісної підготовки здобувачів вищої освіти (першого-третього рівнів), впливати на формування особистості майбутніх фахівців, а також забезпечувати комфортну атмосферу для роботи і відпочинку співробітників. Установлено, що першими очільниками кафедри педагогіки були професори А. Валицький, М. Лавровський, пізніше - Т. Гарбуз, І. Синепол, С. Литвинов, М. Григорьєв. Саме вони доклали зусиль для повночінного становлення кафедри педагогіки. Подальший ї̈ інтенсивний розвиток відбувся в період управління професорами А. Зільберштейном, Л. Поповою, доктором педагогічних наук, професором I. Федоренком, докторами педагогічних наук, професорами, членами-кореспондентами НАПН України В. Лозовою, А. Троико.

3'ясовано, щео виховний потенціал, як «комплекс засобів», "резерви», «потужність» $\epsilon$ основними показниками кафедри, члени якої об'єднані спільними ідеями, віддані служінням професії, педагогічній науці на основі взаємодовіри, взаємоповаги, взаємопідтримки.

У статті визначено $і$ схарактеризовано умови, за яких здійснюється реалізачія виховного потенціалу кафедри: знання і шанобливе ставлення до історії кафедри; урахування науково-педагогічного досвіду очільників і провідних науковиів кафедри; наявність наукових шкіл, продуктивність їх діяльності; потужний склад кафедри, який ініџіюе $i$ реалізуе стратегію $i$ місію університету; організачійно-методичне забезпечення роботи кафедри, щьо дисциплінує $i$ стимулюе викладачів до активної діяльності; персональна унікальність членів кафедри.

На конкретних прикладах показано ефективність реалізачії виховного потенціалу кафедри: високі показники у науковій діяльності; посилення особистісної ініџіативи членів кафедри у розробці наукових проєктів, грантів, навчальних дисииплін; застосування інноваційних технологій; посилення 
індивідуальної роботи із здобувачами всіх рівнів; запровадження заходів заохочення викладачів і традицій кафедри.

Ключові слова: кафедра, виховний потенціал, показники, умови, потужність кафедри, очільники, наукові школи.

Boiarska-Khomenko A. V., Zolotukhina S. T., Shtefan L. A. Educational potential of the Department of Educology and Innovative Pedagogy. Based on the analysis of the activities of the Department of Educology and Innovative Pedagogy, its educational potential is revealed in the article. The author emphasizes that it is the department that should create the conditions for formation of its members' ability to organize the process of high-quality training of higher education applicants (the $2^{\text {nd }}$ the $3^{\text {rd }}$ levels), influence the formation of future specialist's personality as well as provide a comfortable atmosphere for work and rest of all members of the department.

It is revealed that the educational potential, being "a complex of means", "reserves" and "power", is the main indicators of the department, whose members are united by common ideas, devotion to the profession and pedagogical science on the basis of mutual trust, mutual respect and mutual support.

The author determines and characterizes the conditions under which the implementation of the educational potential of the department is carried out. They are: knowledge and respectful attitude to the history of the department; taking into account the scientific-pedagogical experience of the heads and prominent scientists of the department; development of scientific schools and productivity of their activities; powerful teaching staff of the department, initiation and implementation of the strategy and mission of the university by the teaching staff; organizational and methodical support of the activities of the department, which disciplines and stimulates lecturers to be active; personal uniqueness of the members of the department.

The effectiveness of implementation of the educational potential of the department is shown on specific examples. It includes high indicators in scientific activity; strengthening of the department members' personal initiative in the development of research projects, grants and subject; the use of innovative technologies; strengthening of individual work with applicants of all levels; the introduction of incentives for the teaching staff and traditions of the department.

Keywords: department, educational potential, indicators, conditions, power of the department, head, scientific schools.

Вступ. Кафедра, як свідчить досвід роботи вищих закладів освіти, є важливим елементом в їх структурі. Саме кафедра несе основну відповідальність за якість навчання і підготовку майбутніх фахівців, за змістове, функціональне, науково-дослідницьке, навчально-методичне іiі забезпечення, за формування особистості фахівця, який має бути готовим до праці в мовах ринкових відносин, творчо, креативно, мобільно реагувати на виклики сьогодення.

Кафедра як структурний елемент освітнього закладу вже була предметом окремих досліджень. Так, роль і значення кафедри в контексті розвитку вищої 
педагогічної освіти, а також підготовки майбутніх учителів підкреслювали А. Алексюк, М. Свтух, С. Золотухіна, В. Лозова, Л. Попова, І. Прокопенко, Л. Штефан та ін.

Дослідники Л. Зеленська, О. Друганова, О. Антоненко, О. Микитюк, розкриваючи суть, зміст і напрями науково-дослідної роботи освітнього закладу в історичному аспекті, звертали увагу на місце і роль у цьому процесі кафедри.

Окремі проблеми, пов'язані 3 діяльністю кафедр, висвітлено в працях Ю. Шарова (рейтингування кафедр і оцінювання діяльності викладачів); К. Астахової, Н. Дем'яненко, Л. Вовк (тенденції розвитку кафедр педагогіки); В. Жука (роль кафедр у підготовці вчителів в Університетах Наддніпрянської України у дореформену добу XIX ст.); С. Резника (управлінські аспекти діяльності кафедр).

Цілісне дослідження представлено О. Башкір, у якому розкрито становлення і розвиток кафедр педагогіки: зміст, напрями діяльності, форми і методи роботи викладачів, подано унікальний архівний матеріал, який характеризує ї очільників. Але, не зважаючи на обсяг виконаної дослідницької роботи, доцільним, на наш погляд, $є$ визначення і розкриття виховного потенціалу кафедр, зокрема, на прикладі кафедри освітології та інноваційної педагогіки, як унікальної, найстарішої в Україні.

Мета статті: на основі аналізу архівних джерел, науково-публіцистичних статей визначити i розкрити виховний потенціал кафедри як середовища реалізації професійної компетентності їі педагогічного колективу.

Методи дослідження: аналіз історико-педагогічної літератури, архівних матеріалів, узагальнення результатів, здійснених в Україні досліджень, прогнозування напрямів подальших наукових пошуків кафедри педагогіки.

Результати. Серед важливих і надзвичайно складних функцій кафедри слід визначити виховну. Саме кафедра має створювати таке середовище, в якому i відбувається формування і розкриття здатності у викладачів розуміти, поважати один одного, співчувати i радіти за колег. Саме наявність духовного i інтелектуального, як провідної концепції кафедри, забезпечує потяг ії членів до пізнання істини, до неперервної освіти, саморозвитку, виховання почуття міри, відповідальності, творчості та інноваційності. Тільки за таких умов буде здійснюватись виховний вплив кафедри, реалізовуватися їі виховний потенціал. А це означає, що кафедра, яка має таку силу, можливості, міць, резерви, сукупність засобів, має створювати комфортний мікроклімат для роботи ii членів, забезпечувати належні умови для розкриття науково-освітнього потенціалу кожного викладача, працівника кафедри.

Виховний потенціал кафедри закладався з моменту їі створення. Так, кафедра була заснована 5 листопада 1850 р. згідно Постанови Міністерства Народної 
освіти «Про створення в університетах особливої кафедри педагогіки» 3 метою педагогічної підготовки вчителів, яка 31852 р. діяла як загальна. Створення таких кафедр було обумовлено прагненням досягти поєднання наукової, освітньої, адміністративної діяльності університетів із середньою освітою, об'єктивною потребою здійснення педагогічної підготовки вчителів на базі педагогічних інститутів, які відкривалися у складі університетів. Поступово чисельність членів кафедри зростала, вона ставала потужною. Цьому сприяло виважене призначення іiі очільників. Керівниками кафедри були, як правило, науковці, високоосвічені професіонали, які обізнані в педагогічних проблемах, цінували педагогічну науку і власними грунтовними наробками розвивали іiі.

Першими очільниками кафедри педагогіки були професори А. Валицький, М. Лавровський, пізніше - Т. Гарбуз, І. Синепол, С. Литвинов, М. Григорьєв. Саме вони доклали зусиль для повноцінного становлення кафедри педагогіки. Подальший іiі інтенсивний розвиток відбувся в період управління професорами А. Зільберштейном, Л. Поповою, доктором педагогічних наук, професором I. Федоренком, докторами педагогічних наук, професорами, членамикореспондентами НАПН України В. Лозовою, А. Троцко.

Особливістю очільників кафедри було і те, що значна більшість із них мали педагогічну освіту, і перш ніж зайнятись наукою, працювали в школі, в органах освіти на різних посадах. Це не могло не вплинути на характер, зміст роботи педагогічного колективу. Наприклад, I. Федоренко і В. Лозова сприяли створенню експериментальних майданчиків у школах міста і області, займались розробкою теорії наочності, здійснювали дослідження історії розвитку педагогіки як науки, обгрунтовували теоретико-методичні засади формування навчальних умінь і навичок учнів молодших класів, а також цілісного підходу до розвитку пізнавальної активності старшокласників у різних видах діяльності.

Саме завдяки їх професійним управлінським умінням, науковому потенціалу, особистісним якостям кафедра завжди на високому рівні виконувала наукові, навчально-методичні завдання, формувала колектив однодумців, середовище, в якому було комфортно працювати, реалізовувати свій потенціал, професійно зростати. Завідувачі кафедри, як науковці, яких знали в Україні і далеко за іiі межами, створили наукові школи: дидактичну, яку очолювали I. Федоренко, В. Лозова; історико-педагогічну, керівником якої була Л. Попова, загальнопедагогічну, засновником якої був А. Зільберштейн.

Ці школи продовжують і сьогодні своє існування завдяки діяльності їх учнів, докторів педагогічних наук, професорів: С. Золотухіної, О. Іонової, Т. Рогової, Л. Рибалко, О. Попової, Л. Штефан. Крім того, подальший розвиток наукових шкіл відбувається в різних напрямах відповідно сучасним викликам 
такими науковцями, як: доктори педагогічних наук, професори - Л. Зеленська, Н. Ткачова, В. Ворожбіт-Горбатюк, О. Друганова.

Дієвість, мобільність, виховний потенціал сучасної кафедри доводить i демонструє потужний iï склад, серед яких 16 докторів педагогічних наук, 8 кандидатів педагогічних наук. Така кафедра спроможна забезпечити реалізацію всіх напрямів роботи: навчально-виховний, науково-дослідний, методичний, організаційний. Професорсько-викладацький склад кафедри постійно переймається відповідністю вимогам часу, 3 цією метою розробляються i читаються нові курси для бакалаврів, магістрів, здобувачів вищої освіти третього (освітньо-наукового) рівня. Зокрема, тільки в цьому році на кафедрі викладається 37 нових навчальних дисциплін.

Підготовка кадрів вищої кваліфікації вимагає від викладачів кафедри систематично оновлювати, модернізувати ii зміст. Наприклад, на програмі «Освітологія» для магістрів запропоновано викладання «Продуктивної педагогіки», «Супервізія і коучинг в освіті», «Ліцензування та акредитація освітньої діяльності». На програмі «Освітні, педагогічні науки» для здобувачів вищої освіти третього (освітньо-наукового) рівня - «Науковий стендап», «Методологія, технологія науково-педагогічного дослідження та презентація його результатів», «Грантова та проєктна діяльність», «Дизайн науковопедагогічного мислення».

Важливим у цьому контексті слід назвати організацію різних науковометодичних, практичних заходів і форм роботи; здійснення стажування членів кафедри 3 метою забезпечення їх постійного саморозвитку та самовдосконалення не тільки у ЗВО України, а й Польщі, Фінляндії, Турції, а також керівництво підготовкою кадрів вищої кваліфікації: докторів філософії, докторів педагогічних наук. Кафедра по праву вважається кузнею кадрів для університету й України.

Особливе місце в роботі кафедри займає зв'язок з академічними установами НАПН України, їі інститутами, філіями і закладами освіти (вищими, середніми). У свій час, відповідно до наказу МОН УРСР «Про затвердження опорних кафедр педінститутів республіки» (1981р.), кафедра, як опорна, виступала організатором спільних нарад завідувачів педагогічних кафедр Глухівського, Горлівського, Полтавського, Слов'янського інститутів. Досвід такої роботи дав свої наслідки. Сьогодні кафедра прагне бути ініціатором у здійсненні державних планів, щодо підготовки вчителів. Кафедра неодноразово ставала переможцем 3 наукової роботи і зараз постійно ініціює нові форми співдружності з різними освітньо-науковими установами.

Особливості сучасного освітнього процесу сьогодні спричинили прояв креативності, гнучкості, сміливості, професіоналізму наших викладачів. 
Кафедра набуває унікального досвіду здійснення грантової діяльності (доктори педагогічних наук, професори: А. Боярська-Хоменко, О. Башкір, Т. Собченко, Т. Твердохліб); розробки освітньо-наукових програм зі спеціальності 011 освітні, педагогічні науки, виконання обов'язків гарантів ОНП (доктори педагогічних наук, професори: Л. Рибалко, Л. Зеленська). Визначною науковометодичною подією слід назвати і проведення майстер-класів, тренінгів на дистанційній платформі ATOMS для вчителів, викладачів не тільки Харківської області, а й усієї України, з використання цифрових серверів у освітньому процесі та наукових дослідженнях у змішаному навчанні для здобувачів вищої освіти (доктори педагогічних наук, професори Т. Собченко, В. ВорожбітГорбатюк).

Діяльність кафедри змістовно i процесуально збагачена наявністю i конкретною роботою трьох лабораторій: науково-методична лабораторія освіти дорослих і педагогічного проєктування (науковий керівник: доктор педагогічних наук, доцент А. Боярська-Хоменко); науково-методична лабораторія інновацій в освіті (науковий керівник: доктор педагогічних наук, професор Н. Ткачова); науково-методична лабораторія духовно-інтелектуального виховання та навчання (науковий керівник: доктор педагогічних наук, професор Л. Рибалко).

Зазначене характеризує кафедру як сучасну, прогресивну, інноваційну. Підкреслимо, прагнення бути в тренді засвідчують і постійні пошуки викладачів не тільки в організації освітнього процесу, а й у реальних кроках щодо ії назви. За період свого становлення і розвитку кафедра змінювала свій статус і назву. Спочатку кафедра була загальноуніверситетською, з 2000 року кафедра - у складі фізико-математичного факультету. У різні роки кафедра називалась порізному, як-от: «Кафедра педагогіки і педології», «Науково-дослідна кафедра», «Кафедра педагогіки і психології», «Кафедра педагогіки», «Кафедра загальної педагогіки і педагогіки вищої школи», 3 2021p. - «Кафедра освітології та інноваційної педагогіки».

Виховний потенціал кафедри підтверджує також організація сумісного, змістовного дозвілля. Коли членам кафедри не тільки комфортно працювати разом, а й відпочивати - це високий, якісний показник сформованості колективу, його освітніх, науково-виховних можливостей.

Виховний потенціал кафедри полягає в іії унікальності, неповторності. Тільки на кафедрі «Освітології та інноваційної педагогіки» діє «ArtHUB», ведеться «Книга Пошани», проводиться «Посвята в аспіранти», організуються вебінари сумісно з педагогічними кафедрами м. Харкова та інших регіонів України. Викладачі кафедри започаткували і ведуть рубрику в газеті «Учитель» «Золотий фонд Університету». У період акредитації освітньої програми «011- 
Освітні, педагогічні науки», гарантом, доктором педагогічних наук, професором Л. Рибалко було також відзначено ії змістовність, унікальність та своєрідність.

Як свідчить досвід роботи, виховний потенціал кафедри характеризується, перш за все, викладачами. 3 одного боку, - це колектив професійних, працьовитих, талановитих, творчо налаштованих людей, які відповідально реалізують поставлені перед ними цілі і завдання. 3 іншого, кожен із викладачів - це непересічна особистість, з яскраво вираженими, неповторними рисами, що робить колектив, за твердженням А. Макаренко багатобарвним музичним оркестром, організованим, надійним, цікавим.

Так, чіткість, високий рівень науковості, інформативності викладання курсів педагогічного спрямування для бакалаврів, магістрів, здобувачів третього (освітньо-наукового) рівня вищої освіти, притаманні докторам педагогічних наук, професорам О. Башкір, Л. Зеленській, О. Другановій, О. Поповій, Л. Рибалко, Т. Роговій, Л. Штефан.

Постійне ініціювання нових освітніх заходів у відповідності до сучасних вимог з огляду на Європейські цінності, поєднання глибоких знань нормативної бази 3 реальним освітнім процесом, здійснення юридичної просвіти колег i здобувачів притаманне доктору педагогічних наук, професору В. ВорожбітГорбатюк. Майстерність організації навчально-пізнавальної діяльності здобувачів демонструють доктор педагогічних наук, професор М. Пісоцька, доктори педагогічних наук, доценти Т. Твердохліб, О. Кін, Т. Собченко. Високий клас включення здобувачів вищої освіти в різні види діяльності виявляють доктори педагогічних наук, професори С. Васильєва, С. Лупаренко, Н. Ткачова, кандидати педагогічних наук, доценти А. Балацинова, А. Денисенко, А. Цапко, Л. Калашнікова. Спокійне, розсудливе, викладання педагогічних курсів характерні для кандидатів педагогічних наук, доцентів В. Білик, Г. Дейниченка, В. Ялліної. Отже, кожен викладач кафедри, цікавий, своєрідний, унікальний, що робить процес підготовки майбутніх учителів виховним.

Обговорення. Порівняно 3 попередніми працями, у статті представлено авторський підхід до аналізу питань виховного потенціалу кафедри освітології та інноваційної педагогіки.

Висновки. Таким чином, виховний потенціал кафедри освітології та інноваційної педагогіки надзвичайно потужний і він проявляється у знанні своєї історії, високому професіоналізмі професорсько-викладацького складу, у збереженні традицій, пошуку нових інноваційних заходів роботи, в особливій психологічній атмосфері на кафедрі.

ЛITEPATУPA: 
Башкір О. I. Науково-педагогічна діяльність кафедр педагогіки у вищих педагогічних навчальних закладах України: історико-педагогічний аспект: монографія. X.: Видавництво Іванченка I. С., 2017. 518 с.

Боярська-Хоменко А.В., Денисенко А.О. 3 досвіду організації наукової, навчально-методичної та виховної діяльності кафедри історії педагогіки і порівняльної педагогіки Харківського національного педагогічного університету імені Г.С. Сковороди. Новий колегіум, 2019. № 4, С. 73-77.

Золотухіна С. Т., Башкір О. І. Освітні зв’язки кафедр педагогіки закладів вищої педагогічної освіти. Теорія і практика управління соціальними системами. 2019. № 3.

Золотухіна С. Т., Зеленська Л. Д. Кафедра загальної педагогіки та педагогіки вищої школи в структурі Харківського національного педагогічного університету імені Г. С. Сковороди: сторінки історії. Новий колегіум, № 4, 2019. С. 90-99.

Штефан Л. А. Наукові школи кафедри історії педагогіки і порівняльної педагогіки. Новий колегіум, № 1, 2020. С. 86-90.

\section{REFERENCES:}

Bashkir, O. I. (2017). Naukovo-pedahohichna diialnist kafedr pedahohiky u vyshchykh pedahohichnykh navchalnykh zakladakh Ukrainy: istoryko-pedahohichnyi aspekt [Scientific and pedagogical activity of departments of pedagogy in higher pedagogical educational institutions of Ukraine: historical and pedagogical aspect]: monohrafiia. Kh.: Vydavnytstvo Ivanchenka I. S., 518 s. (in Ukrainian).

Boiarska-Khomenko, A. V.\& Denysenko, A. O. (2019). Z dosvidu orhanizatsii naukovoi, navchalnometodychnoi ta vykhovnoi diialnosti kafedry istorii pedahohiky i porivnialnoi pedahohiky Kharkivskoho natsionalnoho pedahohichnoho universytetu imeni H.S. Skovorody. [From the experience of organizing scientific, educational and methodological and educational activities of the Department of History of Pedagogy and Comparative Pedagogy of H.S. Skovoroda Kharkiv National Pedagogical University]. Novyi kolehium, № 4, S. 73-77 (in Ukrainian).

Shtefan, L. A. (2020). Naukovi shkoly kafedry istorii pedahohiky i porivnialnoi pedahohiky. [Scientific schools of the Department of History of Pedagogy and Comparative Pedagogy]. Novyi kolehium, № 1, S. 86-90 (in Ukrainian).

Zolotukhina, S. T. \& Bashkir, O. I. (2019). Osvitni zviazky kafedr pedahohiky zakladiv vyshchoi pedahohichnoi osvity. [Educational ties of the pedagogy of educational institutions of higher pedagogical education]. Teoriia i praktyka upravlinnia sotsialnymy systemamy. № 3 (in Ukrainian).

Zolotukhina, S. T. \& Zelenska, L. D. (2019). Kafedra zahalnoi pedahohiky ta pedahohiky vyshchoi shkoly v strukturi Kharkivskoho natsionalnoho pedahohichnoho universytetu imeni $\mathrm{H}$. S. Skovorody: storinky istorii. [Department of General Pedagogy and Pedagogy of Higher School in the structure of the H. S. Skovoroda Kharkiv National Pedagogical University: history pages]. Novyi kolehium, № 4, S. 90-99 (in Ukrainian).

\footnotetext{
Інформація про авторів:

Боярська-Хоменко Анна Володимирівна: ORCID: http://orcid.org/0000-0002-1818 3074; доктор педагогічних наук, доцент, завідувач кафедри освітології та інноваційної педагогіки, Харківський національний педагогічний університет імені Г.С. Сковороди, вул. Валентинівська, 2, м. Харків, Україна 61000

e-mail: annaboyarskahomenko@gmail.com
}

Information about the authors:

Boiarska-Khomenko Anna Volodymyrivna: ORCID: http://orcid.org/0000-0002-18183074; Dr. hab. in Pedagogy, Associate Professor, Head of the Department of Educology and Innovative Pedagogy, H. S. Skovoroda Kharkiv National Pedagogical University, Valentynivska street, 2, Kharkiv, Ukraine 61000

e-mail: annaboyarskahomenko@gmail.com 
Золотухіна Світлана Трохимівна:

ORCID: https://orcid.org/0000-0002-3535-

5974, доктор педагогічних наук, професор, професор кафедри освітології та інноваційної педагогіки, Харківський національний педагогічний університет імені Г. С. Сковороди,

вул. Валентинівська, 2, м. Харків, Україна, e-mail: kaf_pedagogik@ukr.net

Штефан Людмила Андріївна:

ORCID: https://0000-0002-6281-980X, доктор педагогічних наук, професор, професор кафедри освітології та інноваційної педагогіки Харківського національного педагогічного університету імені Г.С. Сковороди, вул. Валентинівська, 2, м. 2, Kharkiv, Ukraine, 61166 Харків, Україна, 61166

e-mail: Valeriy.61.sh@gmail.com
Zolotukhina Svitlana Trokhymivna:

ORCID: https://orcid.org/0000-0002-35355974, Dr. hab. in Pedagogy, Professor, Professor of the Department of Educology and Innovative Pedagogy, H. S. Skovoroda Kharkiv National Pedagogical University, Valentynivska, street, 2, Kharkiv, Ukraine, 61000

e-mail: kaf_pedagogik@ukr.net

Shtefan Liudmyla Andriivna:

ORCID: https://0000-0002-6281-980X; Dr. hab. in Pedagogy, Professor, Professor of the Department of Educology and Innovative Pedagogy, H. S. Skovoroda Kharkiv National Pedagogical University, Valentynivska street,

e-mail: Valeriy.61.sh@gmail.com

Цитуйте цю статтю як: Боярська-Хоменко А.В., Золотухіна С. Т., Штефан Л. А. Виховний потенціал кафедри освітології та інноваційної педагогіки. Теорія та методика навчання та виховання. 2021. № 51. С. 34-43.

DOI: $10.34142 / 23128046.2021 .51 .04$

Дата надходження статті до редакції: 26.08.2021 p.

Стаття прийнята до друку: 14.09.2021 р. 